\title{
Increasing Dedication Awareness in Disadvantaged Areas for Geography Education Students Through PBL (Project Based Learning)
}

\author{
$1^{\text {st }}$ Fatiya Rosyida \\ Universitas Negeri Malang \\ Malang, Indonesia \\ fatiya.rosida.fis@um.ac.id
}

\author{
$2^{\text {nd }}$ Khofifatu Rohmah Adi \\ Universitas Negeri Malang \\ Malang, Indonesia \\ khofifatu.rohmah.adi.fis@um.ac.id
}

\author{
$3^{\text {rd }}$ Nailul Insani \\ Universitas Negeri Malang \\ Malang, Indonesia \\ nailul.insani.fis@um.ac.id
}

\begin{abstract}
Educational development in undeveloped regions needs contributions from all parties. Main problem of development in disadvantaged areas is the low interest of teachers and pre-service teachers to serve in the area. Low readiness of teachers and pre-service teachers is caused by a lack of knowledge from real physical, social and educational conditions in remote regions. interviews were conducted with students in class $K$. Result was that $12.82 \%$ wanted to serve in remote areas and $87.18 \%$ were unwilling. This condition is very worrying because if pre-service teachers do not care about the development of education in disadvantaged areas, education development will be hampered. Therefore, this study aims to foster a willingness to serve students in disadvantaged areas by implementing Project Based Learning. Method used in this research is Classroom Action Research. Research subjects were students of the 2015 geography education program on social geography courses. Research instrument was an interview guide and observation sheet. Data were analyzed descriptively qualitatively. Results showed that there was an increase in the number of students who were willing to serve in disadvantaged areas from $14.71 \%$ to $44.11 \%$. Students' willingness to serve in remote regions requires to be improved by implementing innovative learning that can increase awareness of serving in all courses.
\end{abstract}

Keywords: dedication awareness, $P B L$

\section{INTRODUCTION}

Development of disadvantaged regions is one of the crucial problem in Indonesian nation. Indonesia's least developed region are quite large. Base on data from Bappenas/PPN or the ministry of national development planning and the ministry of village, development of disadvantage area, transmigration says that in 2004 there were 199 district including left area. Based on that data, 123 districts $(63 \%)$ are in Eastern Indonesia, 58 districts (28\%) are on Sumatra, and 18 district (8\%) are in java and Bali. In 2009 there were 183 regencies in the regions that were left behind. There were 122 area including disadvantage regions in 2015. The topmost distribution of permanent remote area are in eastern of Indonesia [1]

Although number of remote areas continues to decrease, we still need to overcome this so that there are really no more disadvantaged areas in Indonesia. This is done on the grounds that the existence of disadvantaged areas shows the development gap between regions in Indonesia. In the perspective of political economy, inequality occurs, due to the existence of global capitalism, which seeps and controls almost all developing countries, including Indonesia [2]. Inequality of development that occurs has an impact on three realities, namely poverty, unemployment and loss. Other effects caused by extreme inequality include economic inefficiency, weak stability and social solidarity, and high inequality are generally seen as injustice [3].

Problem of uneven development must find a solution immediately. in this case actually, the Government has sought to accelerate the development of disadvantaged areas. as stated in the 2019 National Medium-Term Development Plan (RPJMN) 2015. These efforts include 11 development strategies, namely: 1) economic development of communities in disadvantaged areas; 2) increasing accessibility that connects remote areas and growth centers by upgrading transportation facilities and infrastructure; 3) improving the quality of human resources, science and technology, and governance capacity of underdeveloped local government institutions; 4) accelerate the fulfillment of Minimum Service Standards for basic public services in underdeveloped areas; 5) provide special benefits for health, education allowances and agricultural extension and village assistants in underdeveloped areas; 6) submission of regulations on disadvantaged areas and provide incentives to the private sector in implementing business demands in disadvantaged areas; 7) improvement of infrastructure development in city border areas, such as border areas; 8) fostering disadvantaged areas by increasing the capacity of local government protection and increasing human resources: 9) 
encouraging and supporting regional development and transmigration in an effort to increase inequality between regions, 10) improving coordination and supporting sector relations in supporting development of disadvantaged regions, and 11) Enhancing Development of the Provinces of Papua and West Papua

One important strategy is to grow quality of human resources. Education is a mean that can be done to increase quality of human resources. Education serves as a catalyst for accelerating development as well as an indicator of the success of human development. This is in line with the Millennium Development Goals (MDGs) which make education an indicator of development success. Aim is the achievement of fair and equitable education for all people regardless of gender, ethnicity, race, and religion. An indicator of the success of these objectives is the Human Development Index (HDI). The high Human Development Index shows the high quality of human resources in a country. This condition can occur if the state can serve the basic rights of its citizens.

Education is an important part of human resources formation so it is very reasonable to say as a catalyst [4]. This is because main factor of development is human resources in both quantity and quality. High quantity human resources will increase overall development productivity. Increased productivity will escalate the rate of economic growth. Not only quantity factor, human resources quality must be considered. Human resources quality will further enhance development because of the emergence of innovation and technology. However, developing countries the quantity factor is still the main factor. This is different from developed countries that make quality a priority of development [5].

Education has the most urgent contribution in determining human quality. Humans have knowledge through education. Knowledge possessed by humans is expected to be a provision for a better life (life skills). Thus it can be concluded that education and quality of life of a person has a positive correlation. Higher level of person's education, better the quality of human life. This is due to the knowledge that can be used to organize itself. The higher the quality of life of the population in a country, higher level of economic growth and social welfare [5].

Behaviors and perspectives in living life can be changed by education. Poverty can be reduced by education [6-7]. This is because education can provide the knowledge and skills needed to better life. Knowledge and skills make human have many opportunities to choose a job that suits their wishes. In addition, it can increase work productivity so that income can increase. Thus it can be concluded that education can reduce poverty, improve social status, reduce exclusion [8]. In the end it can improve the quality of life and realize community welfare.

Based on previous exposure, education development must be carried out as a whole, mainly in disadvantaged areas.
Contribution of all elements is needed for education development in undeveloped regions. Willingness of teachers and pre-service teachers to be very low to serve in the area is a major problem which causes the development of education has not been optimal. Very poor knowledge about social and educational conditions in disadvantaged areas

Another factor which causes the development of education in disadvantaged areas is not going well. These factors are the concern for education in underdeveloped areas. This condition also occurs in pre-service teachers (students) from geography education programs. This is known based on interviews. The interview results showed that 34 students were not willing to serve in the highest areas and only 5 students were interested in serving in disadvantaged areas. This condition is very sad because education development will not succeed, if pre-service teachers are not interested in developing education in disadvantaged areas. Therefore, strategies need to be undertaken to foster student readiness with project-based learning.

Learning models that can foster awareness and concern for education in disadvantaged areas are project-based learning. This is because PBL provides an opportunity to be active in being able to actively learn and build their own knowledge so as to foster desired attitudes. Student involvement in investigating problem solving and meaningful activities can give students the opportunity to work independently to build their own knowledge through tangible products is another advantage of PBL (9-10]. The project-based learning model takes six steps, namely: (1) starting with essential questions, (2) designing a plan for the project, (3) making a schedule (4) monitoring students and project progress (5) evaluating the results, (6) evaluating the experience [3].

\section{METHOD}

This research is Classroom Action Research. Classroom Action Research (CAR) aims to foster awareness of service in disadvantaged areas for students using a project-based learning model. Classroom Action Research is carried out in two cycles to achieve the desired results. Each cycle consists of four stages, namely: (1) planning, (2) implementation, (3) observation and (4) reflection. The four stages in the cycle of class action research are described as a spiral (fig 1): 


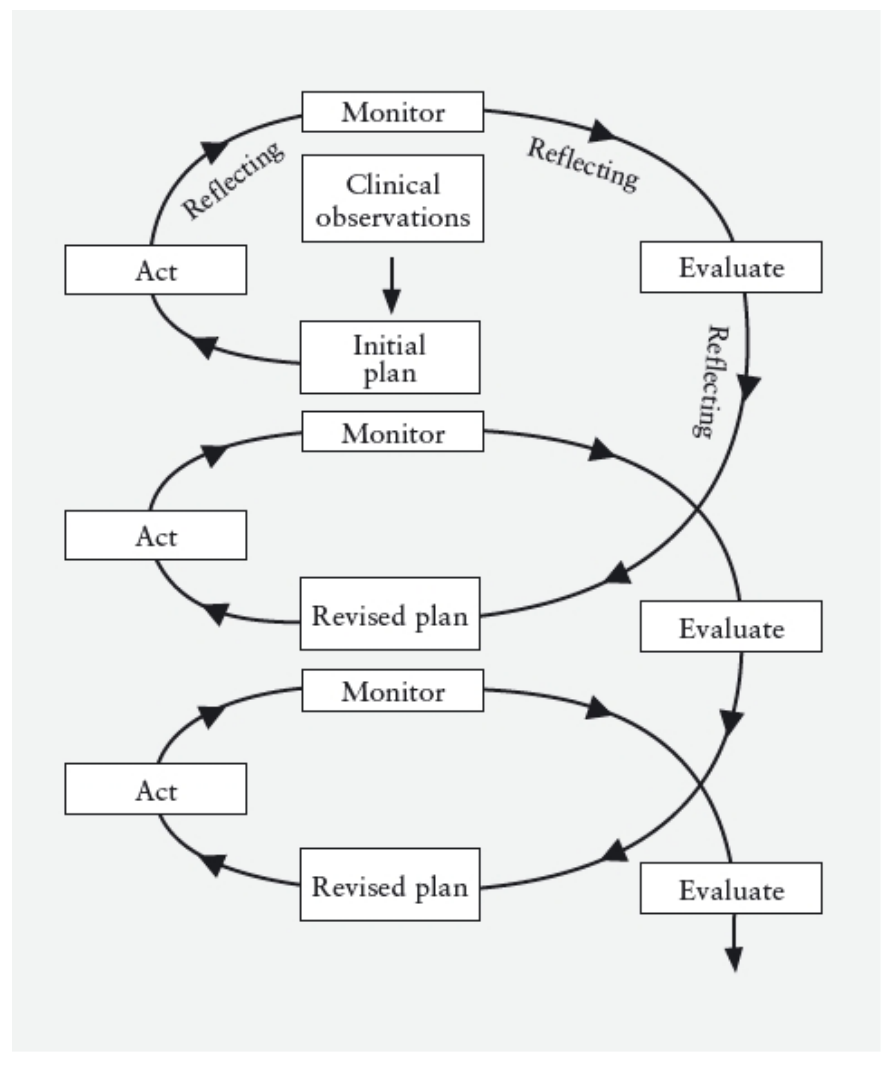

Fig 1. Action Research Cycle (adapted Kemmis Class and Mc Taggart [11])

Subject of study was class K with a total of 39, consisting of 28 female and 11 male. These students take social geography courses. Instruments used in this study include (1) interview guidelines. This interview is used to determine student awareness to serve in remote regions. Interviews were conducted at the end of the learning session (2) observation guidelines, observations were made before the action occurred and at the time of the action. Observation before the activity is carried out to find out information about problems encountered in classroom activities. Observation when action is taken to obtain information about the implementation of lectures including lecturer and student activities. Data were analyzed qualitatively. Analyzed data uses three main phases: data reduction, data display, and drawing conclusions and verification. The success of this study occurs when the number of students who have an awareness of dedication in disadvantaged areas has increased.

\section{RESULTS AND DISCUSSION}

Project based learning is applied in this research. Projectbased learning uses six stages of learning. The first stage is "Start with Essential Questions." Essential questions can come from lecturers, students, or collaborations (lecturers and students).
Learning begins with important questions. These questions are at the core of this learning model. The second step is "Designing a Plan for the Project." In this step, students accompanied by the lecturer make project plans to answer the questions that were formulated in the first stage. For proper project design, information regarding questions needs to be explored more deeply. Information search can be done by asking speakers, discussing with lecturers or other students, reviewing literature in book form or searching for information on the internet. If the information is fulfilled, students can easily design the project. After the information is collected, students formulate hypotheses as temporary answers to questions

The third stage is "Making a Schedule" and the fourth stage is "Monitoring Students and Project Progress". At this stage, students create a schedule for implementing projects and conducting projects accompanied by lecturers. Students conduct experiments, observations, interviews, distribute questionnaires or other activities in accordance with the steps that have been designed in the previous stage. The fifth stage is to assess the results. The results here are the overall results (products) during project implementation. The product assessment is conducted as a lecturer reference in measuring the achievement of learning competencies, measuring the level of progress of each student, providing feedback on the level of understanding that students have achieved, and assisting the lecturer in designing the next learning strategy. Outcome assessment is the act of analyzing the product of a project that has been implemented by students

Evaluate Experiences is the sixth stage of project-based learning. This stage is the final stage in this learning model. Lecturers and students reflect the activities and results of the project at the end of learning. Students are asked to express their feelings and experiences while working on the project. Lecturers and students also hold discussions to improve learning performance. This activity has the aim to answer problems that arise at the beginning of learning.

There has been an increase in students' awareness of geography education in providing services to remote areas after Project Based Learning activities. The increase occurred by $29.4 \%$. Awareness of students whose beginning was $14.7 \%$ of the total to $44.11 \%$. Increased student awareness in the first cycle by $5.8 \%$. The second cycle also experienced an increase in student awareness by $23.61 \%$. At the end of the study Awareness increases. Progress of student awareness can be seen in fig 2.

This condition shows that the implementation of projectbased learning has succeeded in increasing student awareness. Although the success rate of this study is only half of the number of students in the class. This happens because changing attitudes takes a long time. Therefore, continuous effort needs to be made in learning. Efforts are not only made not only in this social geography but also in other subjects. These efforts are made to increase motivation so that pre-service teachers are ready to teach in disadvantaged areas. 


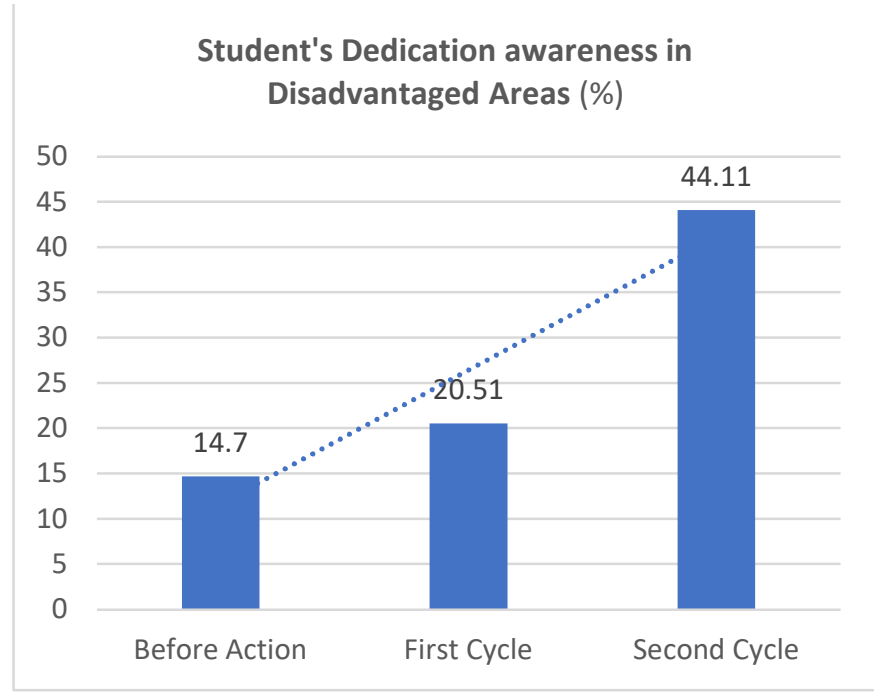

Fig 2. Student's Dedication awareness in Disadvantaged Areas (\%)

Increased student awareness is caused by several factors. These factors are changes in the information they obtain. They find new information that is different from information previously believed. Their initial perception was that occupying disadvantaged areas would not be easy due to low welfare levels and inadequate facilities. Another difficulty living in remote areas is that they have to adapt to different environmental conditions, both socio-cultural and physical conditions. The problem that arises is that the socio-cultural conditions are different from the place of origin, such as language and behavior that is harder than the tribe (Javanese). They are also worried about war between tribes, like in Papua. The physical condition of disadvantaged areas has low accessibility because development has not yet been reached, making it isolated from other areas.

Their perception of the condition in remote areas is changing. These changes occur because the project aims to analyze the problems of education in disadvantaged areas and strategies to solve those problems from a geographical perspective. They study the problem of education in disadvantaged areas. The problems they found were high dropout rates due to low student interest in high school, inadequate facilities, low number of teachers, low school accessibility, incompatible teacher education qualifications, and low teacher welfare. "Justification" for students' assumptions made those who were initially ready to teach in disadvantaged areas disagreeable. Initially as many as five people were willing, only two were ready. They feel unable to adapt to these conditions becomes the reason for students to be unwilling. Students who remain ready to serve because they come from these remote areas. However, there are also students who are touched and willing to teach in disadvantaged areas
New information about [programs implemented to address educational problems in small areas such as Indonesia Mengajar, SM3T, and GGD, can increase their motivation to serve. This program has inspired them to be willing to be involved in the advancement of education in disadvantaged areas. in addition, they are also motivated by information about policies regarding the provision of teacher benefits in disadvantaged areas. Knowledge of this information makes those who were not previously interested in becoming teachers interested. Initially as many as $10.26 \%$ of students who were willing to serve, became $20.51 \%$. The factors that make them interested are 1) welfare guarantee, the teacher has a special allowance. Special allowances are explained in the Teacher and Lecturer Law article 18, which states that special allowances for teachers are one-time salary and provide housing facilities. 2) adequate teaching competence 3) feeling more useful, and 4) opportunities for tourism exploration.

Another factor that led to an increase in students' awareness to serve was a project delivered in class about several success stories to develop remote villages in various fields. One group presented a video of the success story. They are motivated to serve in remote areas after watching videos. There was a denial of student awareness by $44.11 \%$. They realize the conditions and problems in disadvantaged areas are challenges that must be faced. In addition, they want to contribute and carry out concrete activities in the development of education in disadvantaged areas. The story in the video has inspired them. The characters in the video are able to make real changes to disadvantaged areas, making students think that they can also make changes too.

Based on the foregoing, the information on the conditions and the real problems facing education in disadvantaged areas, efforts should be made, and inspirational story about the success of the development of remote areas can change their view. The view changes make them willing to serve in areas that are less fortunate. Project-based learning model can be successful because of topics may change the outlook or their perception of the state of education in Indonesia, especially in remote areas. Moreover, this study allows students to discover real problems occur. Students are also trying to find a solution to overcome the problems they find. Project-based learning not only teaches students to analyze the relationship between theoretical information and practice, but also motivates students to reflect on what they are learning in the form of real projects [12-13].

Project-based learning influences attitude change [9-10; 1317]. Attitude change is caused because this model involves students in solving real problems faced by conducting collaborative investigations. In addition, this project-based learning provides opportunities for students to actively engage in cognitive processes. This model also provides direct experience for students. Learning not only provides knowledge to students but must be understood as a reconstruction of an ongoing experience [18]. This experience is gained by active 
learning, thinking, feeling and understanding. Students not only transfer knowledge from outside but also create meaning and make their own interpretations of the world through experiences gained [19].

Besides providing real experience, Project Based Learning can provide the opportunities needed to dig into the topic content, investigate it in depth and better understand all of the uniqueness. [21-23]. These studies also prove that project-based learning can lead them to understand more about problems of education in underdeveloped areas. In fact, they also examined how solutions should be applied to overcome the problem of education in disadvantaged areas. In other words, project-based learning can influence attitudes because they can build their own knowledge. They are also actively involved in finding the information they need. Information obtained can be used to solve the problem. Resolving the problem is done by connecting theories with the reality in their environment $[10 ; 13]$.

Information or stimulus is interpreted and organized in cognitive processes. After that process, then comes the positive and negative evaluation of a condition or an object. Assessment of conditions is called perception. Perception is the opinion, judgment, and beliefs that arise in a person about an object or certain conditions based on sensory stimulation or data received [24]. Students receive information as stimuli and then respond to these inputs by involving the experiences of objects related to the information they receive. Through their cognitive and affective abilities, students can recognize, assess and conclude information/stimulus.

Perception can occur through three stages, including 1) Perceptual inputs 2) Perceptual throughput, and 3) Perceptual outputs. Perception begins with the stimulus. Stimulus is everything in our environment that has the potential to be felt. It can include things that must be seen, touched, heard, or even accepted by our sensitive senses. Thus all settings where occasion occured, which contribute to the occurrence of occasion, can be regarded as perceptual input.

The second stage is perceptual throughput. At this stage include receiving, selecting, organizing, and interpenting. After receiving stimuli from the environment, some are selected for further processing while others are filtered. this happens because it is possible for a person to choose all the stimuli he sees in the environment. There are two types of factors that influence the selection of stimuli. It is associated with the external and internal stimuli and associated with the recipient. There are several types of external and internal factors..

After the stimulus is chosen, it is arranged in several forms to make sense from it. The various forms of organizing stimuli are grouping of basic level of perception, simplification, and closer. the perception input that has been organized must be interpreted by the observer so that he can feel and extract some meaning from what is happening in the situation. They interpret meaning selectively from how they feel and arrange it based on their own assumptions about things, people, and situations. They judge and interpret it as good/bad, beautiful/ugly and so on which is a relative term. In the process, misinterpretation may occur. Interpretation of stimuli is influenced by the situation in which perceptions occur, the characteristics of stimuli, and the characteristics of taste. The third factor affecting the total perceptual process

The final stage of the process of perception is actions. As a final result, action is a response to environmental stimuli. Perceptual output occurs when the final deceptive trough output occurs in the form of an interpretation of the stimulus. This release may include hidden action development of attitudes, opinions, beliefs, the effect of the stimulus is being considered. This release along with other factors that influence human behavior could lead to behavior. Perception process can be seen in Fig 3.

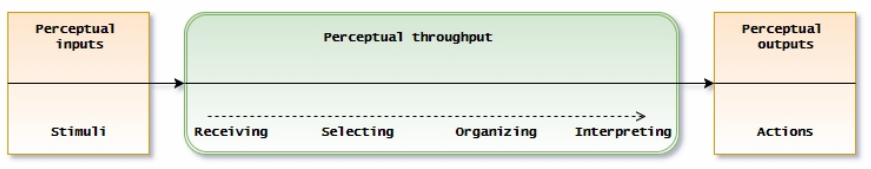

Fig 3. Process of Perception

The action that can be taken to increase students' awareness to serve in undeveloped region is by changing perceptions. Change in perception by providing positive information about education in disadvantaged areas. information or stimulation is knowledge and experience. They get knowledge and experience in learning using the project Based learning model. Perception can be influenced by 2 factors: 1) Frame of reference is a framework of knowledge that is owned and obtained from education, reading, research, or other means and 2) Field of experience is an experience that has been experienced alone and is inseparable from the environment [25].

Perception that is formed as a basis for determining people's behavior. This can be interpreted that perception influences a person's attitude [10; 26-28]. Positive perception of education conditions in remote regions will make students willing to serve. Conversely, negative perceptions will make them not want service in disadvantaged areas. Therefore, efforts should be made to create positive perceptions about education in disadvantaged areas so that an increasing number of teachers and pre-service teachers are willing to serve there.

\section{CONCLUSION}

Students' awareness of serving in disadvantaged areas can be increased by project-based learning. This is indicated by an enhancemet in number of students who are ready to serve in disadvantaged areas. Preliminary data shows that $14.71 \%$ of students are willing to serve and an increase of $44.11 \%$. Students' willingness to serve in disadvantaged areas needs to be grown by applying learning that can increase motivation. 


\section{ACKNOWLEDGMENTS}

We are grateful to the students who participated, geography department lecturers who have been willing to discuss this research, and all those who have helped.

\section{REFERENCES}

[1] Ministry of Village, Development of Disadvantaged Areas, and Transmigration. (2010, February 1). Bappenas: RI Has 183 Regencies of Disadvantaged Regions. (http://kemendesa.go.id/index.php/view/detil/994/bappenas-ri-punya183-kabupaten-daerah-tertinggal)

[2] Halim. Abd. 2013. Model of Underdeveloped Regional Development Policy Case Study in Supiori District of Papua Province. Humanity Journal, ISSN 0216-8995. Volume 8 No2.

[3] The George Lucas Educational Foundation. 2005. Instructional Module Project Based Todaro, Michael P, 2003, Economic Development, Eight Edition, Pearson Education Limited, Eidenburg Gate, Harlow, Essex, England

[4] Nazamuddin. 2013. The Contribution of Education to Economic Development: Case of Aceh Province. Enlightenment Journal Volume 7, Number 2, (September) 2013 Pages 90-100. ISSN: 1693 - 7775

[5] Purwanto, Nurtanio Agus. 2006. The Contribution of Education to State Economic Development. Education Management Journal No. 02 / Th II / October / 2006

[6] Sach, Jeffrey D. 2005. The End of Poverty. New York: Penguin Press.

[7] Sen, Amartya Kumar. 2000. Development as Freedom. New York: Anchor Books.

[8] Ustama, Dicky Djatnika. 2009. The role of education in poverty alleviation."Dialogue" JIAKP, Vol. 6, No. 1, January 2009: 1-12

[9] Mahanal, S. et al. 2009. Effect of Project Based Learning Learning on Ecosystem Knowledge on the Attitudes and Learning Outcomes of Students of SMAN 2 Malang. Paper presented at the BKPSL National Seminar on Environment and Interconnection Education. Malang State University.

[10] Adi, Khofifatu Rohmah, et al. 2016 The Effect of Project-Based Social Studies Learning on Perception Character Consumption in Undergraduate Students of Social Studies, Universitas Negeri Malang. Jurnal Teori dan Praksis Pembelajaran IPS Vol. 1 No. 1 April, 2016. Retrieved January 1, 2019 from http://dx.doi.org/10.17977/um022v1i12016p065

[11] Kemmis, S., \& McTaggart, R. (1982). The Action Research Planner. Victoria: Deakin University Press.

[12] Handayani, I Dw A. Trisna, I Wayan Karyasa, and I Nyoman Suardana. 2015. The Coordination of Increasing Understanding of the Concepts and Scientific Attitudes of High School Students Learned by Problem Based Learning and Project Based Learning Learning Models. e-Journal of the University of Education Ganesha Postgraduate Program Science Education Study Program (Volume 5 of 2015).

[13] Grady, K. \& Ibrahim, M. 2014. The Effects of Project-Based Learning on Middle School Students' Academic Achievement and Perception in the Science Classroom. In T. Bastiaens (Ed.), Proceedings of World
Conference on E-Learning (pp. 701-706). New Orleans, LA, USA: Association for the Advancement of Computing in Education (AACE). $\begin{array}{llll}\text { Retrieved January } & 1, & 2019 & \text { from }\end{array}$ https://www.learntechlib.org/primary/p/148804/.

[14] Susanti. 2003. The Effect of Project-Based Learning on Creative Thinking Ability and Students' Scientific Attitudes to Nutrition Materials. MI-PA Teaching Journal, Volume 18, Number 1, April 2013, p. 36-42.

[15] Widiharto, Chr. Argo, et al. 2015. Project-Based Learning in Entrepreneurship Psychology Courses in Improving the Attitude of Student Entrepreneurs http://e-jurnal.upgrismg.ac.id

[16] Al-Rawahi, Sulaeman S. and Abdu Mohammad Al - Mekhlafi. 2015. The effect of online collaborative project-based learning on English as a Foreign Language learners' language performance and attitude. Learning and Teaching in Higher Education: Gulf Perspectives, 12 (2). http://the.zu.ac.ae.

[17] Çakici, Yilmaz and Nihal Türkmen. 2013. An Investigation of the Effect of Project-Based Learning Approach on Children's Achievement and Attitude in Science. TOJSAT : The Online Journal of Science and Technology- April 2013, Volume 3, Issue 2. Retrieved January 1, 2019 from https://www.tojsat.net/journals/tojsat/articles/v03i02/v03i02-02.pdf

[18] Dewey, J., \& Small, A. W. 1897. My pedagogic creed. The School Journal, 25(3), 77-80.

[19] Baş, G. 2011. Investigating the effects of project-based learning on students' academic achievement and attitudes towards English lesson. The Online Journal of New Horizons in Education, 1(4), 1-15.

[20] Ertmer, P. A., \& Newby, T. J. 1993. Behaviorism, cognitivism, constructivism: Comparing critical features from an instructional design perspective. Performance improvement quarterly, 6(4), 50-72.

[21] Baumgartner, E., \& Zabin, C. J. 2008. A case study of project based instruction in the ninth grade: A semester long study of intertidal biodiversity. Environmental Education Research, 14(2), 97-114.

[22] Bell, S. 2010. Project-based learning for the 21st century: Skills for the future. The Clearing House, 83(2), 39-43.

[23] Holm, M. 2011. Project-based instruction: A review of the literature on effectiveness in prekindergarten. River Academic Journal, 7(2), 1-13

[24] Sarlito, Wirawan Sarwono. 2012. Adolescent Psychology. Jakarta: PT. Raja Grafindo Persada

[25] Notoatmodjo, S. 2007. Health Promotion and Behavioral Sciences. Jakarta: PT Rineka Cipta;

[26] Isyanto, Puji. Et al. 2012. Consumer Purchasing Perception and Behavior Study on Aflamart and Indomart in East Teluk Jambe District. Scientific Majors of UNSIKA Karawang, ISSN 1412-86676 Vol. 10 No. 21 Ed. December 2011-February 2012

[27] Kusnadi, Dedi, 2014. Perception of the Attitudes and Interests of Users of Internet Services at Insurance Service Companies. Journal of Organization and Management, Volume 10, Number 2, September 2014, 97-112. Retrieved August 5, 2019 from http://jurnal.ut.ac.id/JOM/article/download/121/115

[28] Demirel, Melek and Miray Dağyar. 2016. Effects of Problem-Based Learning on Attitude: A Meta-analysis Study. EURASIA J. Math., Sci Tech. Ed 2016;12 (8):2115-2137. Retrieved January 1, 2019 from https://doi.org/10.12973/eurasia.2016.1293a 